\title{
Citation Classics from Industrial Marketing Management: Celebrating Forty-Seven Years of Publications on Business-to-Business Marketing Management
}

Adam Lindgreen, Copenhagen Business School and University of Pretoria's Gordon Institute of Business Science $^{1}$

C. Anthony Di Benedetto, Fox School of Business, Temple University ${ }^{2}$

\footnotetext{
${ }^{1}$ Adam Lindgreen, Department of Marketing, Copenhagen Business School, Solbjerg Plads 3, 2000 Frederiksberg C, Denmark and University of Pretoria's Gordon Institute of Business Science, 26 Melville Road, Illovo, Johannesburg, South Africa. E-mail: adli.marktg@ cbs.dk.

2 C. Anthony Di Benedetto, Fox School of Business, Alter Hall 523, 1801 Liacouras Walk, Philadelphia, PA 19122-6083, USA.
} 


\begin{abstract}
This article proposes a categorization of what constitutes a citation classic. General observations reveal, with regard to the top 30 citation classics from Industrial Marketing Management, the number of authors per article, country of origin of the lead author, and type of article (literature review, qualitative methodology, or quantitative methodology). In addition, these citation classics can be classified by topic (firm performance, goods-dominant and service-dominant logics, Internet and high-technology markets, product innovation, relationships and business networks, supply chains, system sellers and systems integrator, third-party logistics providers, and value). Finally, each of the 30 citation classics is introduced, and the classics' theoretical implications to business-to-business marketing management and fields related to (e.g., supply chain management, strategic management, and innovation) or even outside mainstream marketing are discussed.
\end{abstract}

Keywords: business networks, citation classics, downloads, firm performance, goods-dominant logic, high-technology markets, impact factor, internet, relationships, product innovation, service-dominant logic, supply chains, system integrator, system sellers, third-party logistics providers, value. 


\section{INTRODUCTION}

The inaugural issue of Industrial Marketing Management appeared in September 1971. Prior to then, no single journal had been dedicated specifically to academic research in the growing area of business-to-business marketing. Since its inaugural issue, the journal has grown substantially in all quantitative measures. In its eight 2016 volumes, Industrial Marketing Management published 132 articles, totaling 1,556 pages; submission and page counts provide one clear indication of the growing respect Industrial Marketing Management has earned.

One benchmark is the extent to which the articles it publishes are used and cited by the academic community. In 2016 for example, Industrial Marketing Management articles were downloaded 1,153,398 times; the average number of downloads per article was 8,738. This impressive total suggests a widening of the academic community that is finding Industrial Marketing Management content useful for their own research.

Another familiar benchmark of journal impact is the Thomson ISI Impact Factor, which measures the number of citations of a journal's articles. In 2016, Industrial Marketing Management's Journal Two-Year Impact Factor reached 3.166 (the Five-Year Impact Factor was 4.402). Thus, Industrial Marketing Management ranks 33rd among business journals and 37th among management journals. Although growth in these Journal Impact Factors is impressive, it only hints at the expanding influence of the journal. With the introduction of the Google Scholar search engine, new citation counts offer an alternative measure of journal impact and thus additional insights. A 2010 article, ranking marketing journals according to Google Scholar citations, placed Industrial Marketing Management 5th out of 69 journals (Touzani \& Moussa, 2010). 
Additional evidence of its influence in the academic community arises from the meta-ranking of marketing and technology journals by Franke and Schreier (2008). These authors combine 18 rankings of business journals, each using different methodologies and criteria, to obtain a metaranking that provides a robust ranking of overall journal influence (as of 2008). That ranking places Industrial Marketing Management in a very respectable 14th place.

Three reasons for the continued increase in quality and influence of Industrial Marketing Management have been proposed (Touzani \& Moussa, 2010):

(1) Industrial Marketing Management is read by, and is of interest to, academics in related fields such as strategy, management, innovation, and product development, and thus, it has an influence outside the relatively more narrow field of marketing.

(2) The quality of articles published in Industrial Marketing Management has increased, leading to more citations in recent years.

(3) Research topics covered by Industrial Marketing Management have grown in importance.

The majority of the effort to enhance the quality of Industrial Marketing Management comes, of course, from authors who consider this journal a destination for their world-class research into business-to-business marketing management, as well as the more than 400 people who donate their time and talent to serve as reviewers for this journal.

An impressive 3,129 articles have appeared in Industrial Marketing Management since 1971 This special issue is a celebration of the 30 most cited articles from the pages of this journal (Table 1). Despite the fact that the use of citation counts has been questioned (see the 32 criticisms listed by Michalos and Poff [2013] in their review of what constitutes a citation classic), it nevertheless continues to be a meaure which is widely used in academia. As noted, a 
Table 1 Industrial Marketing Management Citation Classics (as of August 2017)

\begin{tabular}{|c|c|c|c|c|c|c|}
\hline ID & Citations & Title & Author(s) & Volume & Issue & Year \\
\hline 1 & 1126 & Issues in supply chain management & $\begin{array}{l}\text { Lambert, D.M., } \\
\text { Cooper, M.C. }\end{array}$ & 29 & 1 & 2000 \\
\hline 2 & 795 & $\begin{array}{l}\text { Learning orientation, firm innovation } \\
\text { capability, and firm performance }\end{array}$ & $\begin{array}{l}\text { Calantone, R.J., } \\
\text { Cavusgil, S.T., } \\
\text { Zhao, Y. }\end{array}$ & 31 & 6 & 2002 \\
\hline 3 & 761 & $\begin{array}{l}\text { The agile supply chain: Competing in } \\
\text { volatile markets }\end{array}$ & Christopher, M. & 29 & 1 & 2000 \\
\hline 4 & 603 & $\begin{array}{l}\text { Innovativeness: Its antecedents and } \\
\text { impact on business performance }\end{array}$ & $\begin{array}{l}\text { Hult, G.T.M., } \\
\text { Hurley, R.F., } \\
\text { Knight, G.A. }\end{array}$ & 33 & 5 & 2004 \\
\hline 5 & 535 & $\begin{array}{l}\text { "Coopetition" in business networks: To } \\
\text { cooperate and compete simultaneously }\end{array}$ & $\begin{array}{l}\text { Bengtsson, M., } \\
\text { Kock, S. }\end{array}$ & 29 & 5 & 2000 \\
\hline 6 & 386 & $\begin{array}{l}\text { The role of trust and relationship } \\
\text { structure in improving supply chain } \\
\text { responsiveness }\end{array}$ & $\begin{array}{l}\text { Handfield, R.B., } \\
\text { Bechtel, C. }\end{array}$ & 31 & 4 & 2002 \\
\hline 7 & 384 & $\begin{array}{l}\text { Value creation in buyer-seller } \\
\text { relationships: Theoretical considerations } \\
\text { and empirical results from a supplier's } \\
\text { perspective }\end{array}$ & $\begin{array}{l}\text { Walter, A., } \\
\text { Ritter, T., } \\
\text { Gemünden, H.G. }\end{array}$ & 30 & 4 & 2001 \\
\hline 8 & 329 & $\begin{array}{l}\text { From goods to service(s): Divergences } \\
\text { and convergences of logics }\end{array}$ & $\begin{array}{l}\text { Vargo, S.L., } \\
\text { Lusch, R.F. }\end{array}$ & 37 & 3 & 2008 \\
\hline 9 & 319 & $\begin{array}{l}\text { It's all B2B... and beyond: Toward a } \\
\text { systems perspective of the market }\end{array}$ & $\begin{array}{l}\text { Vargo, S.L., } \\
\text { Lusch, R.F. }\end{array}$ & 40 & 2 & 2011 \\
\hline 10 & 305 & $\begin{array}{l}\text { A portfolio approach to supplier } \\
\text { relationships }\end{array}$ & $\begin{array}{l}\text { Olsen, R.F., } \\
\text { Ellram, L.M. }\end{array}$ & 26 & 2 & 1997 \\
\hline 11 & 299 & $\begin{array}{l}\text { The benefits of "Guanxi": The value of } \\
\text { relationships in developing the Chinese } \\
\text { market }\end{array}$ & $\begin{array}{l}\text { Davies, H., } \\
\text { Leung, T.K.P., } \\
\text { Luk, S.T.K., } \\
\text { Wong, Y.-h. }\end{array}$ & 24 & 3 & 1995 \\
\hline 12 & 285 & $\begin{array}{l}\text { The impact of information technology on } \\
\text { supply chain capabilities and firm } \\
\text { performance: A resource-based view }\end{array}$ & $\begin{array}{l}\text { Wu, F., } \\
\text { Yeniyurt, S., } \\
\text { Kim, D., } \\
\text { Cavusgil, S.T. }\end{array}$ & 35 & 4 & 2006 \\
\hline 13 & 280 & $\begin{array}{l}\text { The asymmetric relationship between } \\
\text { attribute-level performance and overall } \\
\text { customer satisfaction: A reconsideration } \\
\text { of the importance-performance analysis }\end{array}$ & $\begin{array}{l}\text { Matzler, K., } \\
\text { Bailom, F., } \\
\text { Hinterhuber, } \\
\text { H.H., Renzl, B., } \\
\text { Pichler, J. }\end{array}$ & 33 & 4 & 2004 \\
\hline 14 & 274 & $\begin{array}{l}\text { Value in business markets: What do we } \\
\text { know? Where are we going? }\end{array}$ & $\begin{array}{l}\text { Lindgreen, A., } \\
\text { Wynstra, F. }\end{array}$ & 34 & $\begin{array}{l}7 \\
\text { SPEC. } \\
\text { ISS. }\end{array}$ & 2005 \\
\hline 15 & 266 & Managing in complex business networks & $\begin{array}{l}\text { Ritter, T., } \\
\text { Wilkinson, I.F., } \\
\text { Johnston, W.J. }\end{array}$ & 33 & 3 & 2004 \\
\hline
\end{tabular}




\begin{tabular}{|c|c|c|c|c|c|c|}
\hline 16 & 262 & Success factors in product innovation & $\begin{array}{l}\text { Cooper, R.G., } \\
\text { Kleinschmidt, } \\
\text { E.J. }\end{array}$ & 16 & 3 & 1987 \\
\hline 17 & 261 & $\begin{array}{l}\text { Capturing value creation in business } \\
\text { relationships: A customer perspective }\end{array}$ & Ulaga, W. & 32 & 8 & 2003 \\
\hline 18 & 253 & $\begin{array}{l}\text { An evaluation of divergent perspectives } \\
\text { on customer relationship management: } \\
\text { Towards a common understanding of an } \\
\text { emerging phenomenon }\end{array}$ & $\begin{array}{l}\text { Zablah, A.R., } \\
\text { Bellenger, D.N., } \\
\text { Johnston, W.J. }\end{array}$ & 33 & 6 & 2004 \\
\hline 19 & 245 & $\begin{array}{l}\text { The role of the internet in supply chain } \\
\text { management }\end{array}$ & $\begin{array}{l}\text { Lancioni, R.A., } \\
\text { Smith, M.F., } \\
\text { Oliva, T.A. }\end{array}$ & 29 & 1 & 2000 \\
\hline 20 & 243 & $\begin{array}{l}\text { Business suppliers' value creation } \\
\text { potential a capability-based analysis }\end{array}$ & $\begin{array}{l}\text { Möller, K.E.K., } \\
\text { Törrönen, P. }\end{array}$ & 32 & 2 & 2003 \\
\hline 21 & 234 & $\begin{array}{l}\text { Strategic development of third party } \\
\text { logistics providers }\end{array}$ & $\begin{array}{l}\text { Hertz, S., } \\
\text { Alfredsson, M. }\end{array}$ & 32 & 2 & 2003 \\
\hline 22 & 233 & $\begin{array}{l}\text { Measuring customer-perceived value in } \\
\text { business markets: A prerequisite for } \\
\text { marketing strategy development and } \\
\text { implementation }\end{array}$ & $\begin{array}{l}\text { Ulaga, W., } \\
\text { Chacour, S. }\end{array}$ & 30 & 6 & 2001 \\
\hline 23 & 233 & $\begin{array}{l}\text { Business relationships and networks: } \\
\text { Managerial challenge of network era }\end{array}$ & $\begin{array}{l}\text { Möller, K.K., } \\
\text { Halinen, A. }\end{array}$ & 28 & 5 & 1999 \\
\hline 24 & 229 & $\begin{array}{l}\text { Antecedents of commitment and trust in } \\
\text { customer-supplier relationships in high } \\
\text { technology markets }\end{array}$ & $\begin{array}{l}\text { De Ruyter, K., } \\
\text { Moorman, L., } \\
\text { Lemmink, J. }\end{array}$ & 30 & 3 & 2001 \\
\hline 25 & 227 & $\begin{array}{l}\text { Functions of industrial supplier } \\
\text { relationships and their impact on } \\
\text { relationship quality }\end{array}$ & $\begin{array}{l}\text { Walter, A., } \\
\text { Müller, T.A., } \\
\text { Helfert, G., } \\
\text { Ritter, T. }\end{array}$ & 32 & 2 & 2003 \\
\hline 26 & 215 & Making the most of supplier relationships & $\begin{array}{l}\text { Gadde, L.-E., } \\
\text { Snehota, I. }\end{array}$ & 29 & 4 & 2000 \\
\hline 27 & 213 & Modeling agility of supply chain & $\begin{array}{l}\text { Agarwal, A., } \\
\text { Shankar, R., } \\
\text { Tiwari, M.K. }\end{array}$ & 36 & 4 & 2007 \\
\hline 28 & 213 & $\begin{array}{l}\text { Predevelopment activities determine new } \\
\text { product success }\end{array}$ & Cooper, R.G. & 17 & 3 & 1988 \\
\hline 29 & 210 & $\begin{array}{l}\text { Organizing for solutions: Systems seller } \\
\text { vs. systems integrator }\end{array}$ & $\begin{array}{l}\text { Davies, A., } \\
\text { Brady, T., } \\
\text { Hobday, M. }\end{array}$ & 36 & 2 & 2007 \\
\hline 30 & 210 & $\begin{array}{l}\text { The influence of brand image and } \\
\text { company reputation where manufacturers } \\
\text { market to small firms: A customer value } \\
\text { perspective }\end{array}$ & $\begin{array}{l}\text { Cretu, A.E., } \\
\text { Brodie, R.J. }\end{array}$ & 36 & 2 & 2007 \\
\hline
\end{tabular}


benchmark of an academic journal's influence is the extent to which the articles it publishes are used by the academic community (measured by number of downloads); another is the journal's Thomson ISI Impact Factor (the number of citations of the journal's articles in later publications). An author's impact on the research community often similarly is judged, at least partially, in terms of his or her total number of citation counts and $\mathrm{h}$ index. ${ }^{3}$

Number of citations often is used as a measure of impact. Garfield (1976, p. 419) claims that "less than $25 \%$ of all papers will be cited ten times in all eternity!"; Pendlebury (1991) asserts that $48.0 \%$ of social science articles published in 1984 remained uncited by the end of 1988 . Given this evidence, a large number of citations is likely a good measure of its impact on the field. Nevertheless, how many citations an article needs to be classified as a classic depends on the field (Michalos, 2005).

Michalos and Poff (2013, p. 7) speculate that "the longer an article is available for citation, the better its chances of being cited and turning up in a list of citation classics" (see also Times Higher Education, 2011). For precisely this reason, Bateman (2012) suggests that an author's h index develops over time (i.e., h trajectory). A useful tool for normalizing the measures across authors at different stages of their careers is the $m$ value, as introduced by Hirsch (2005). The $m$ value, or normalized citation rate, reflects an author's $h$ index, divided by the number of years since his or her first publication. It is interesting to note that Michalos and Poff's (2013) expectation does not hold for the 30 citation classics included in this issue (see Table 2). In fact, the data presented in Table 2 suggest that it is the more recent articles, which attain higher normalized citation scores, not the earlier ones. Perhaps these results are evidence of the growing

\footnotetext{
${ }^{3}$ An author with an $\mathrm{h}$ index of $\mathrm{h}$ has published at least $\mathrm{h}$ articles, each of which has been cited in other papers at least $\mathrm{h}$ times.
} 
quality and importance of articles appearing in Industrial Marketing Management, as the results suggest that the newer articles, having higher normalized citation rates, are found to be more relevant to supporting and advancing current research than older "classics."

Table 2 Industrial Marketing Management Citation Classics: Citations and Years

\begin{tabular}{|c|c|c|c|}
\hline Year & ID and citations & Citation average & $\begin{array}{l}\text { Normalized citation } \\
\text { average } \\
(2017 \text { used as base } \\
\text { year) }\end{array}$ \\
\hline 1987 & 16: 262 & 262 & 8.7 \\
\hline 1988 & 28: 213 & 213 & 7.3 \\
\hline 1995 & 11: 299 & 299 & 13.6 \\
\hline 1997 & $10: 305$ & 305 & 15.3 \\
\hline 1999 & $23: 233$ & 233 & 12.9 \\
\hline 2000 & $\begin{array}{l}1: 1126 \\
3: 761 \\
5: 535 \\
19: 245 \\
26: 215\end{array}$ & 576 & 33.9 \\
\hline 2001 & $\begin{array}{l}7: 384 \\
22: 233 \\
24: 229\end{array}$ & 282 & 17.6 \\
\hline 2002 & $\begin{array}{l}2: 795 \\
6: 386\end{array}$ & 394 & 26.3 \\
\hline 2003 & $\begin{array}{l}17: 261 \\
20: 243 \\
21: 234 \\
25: 227\end{array}$ & 241 & 17,2 \\
\hline 2004 & $\begin{array}{l}: 603 \\
13: 280 \\
15: 266 \\
18: 253\end{array}$ & 351 & 27.0 \\
\hline 2005 & 14: 274 & 274 & 22.8 \\
\hline 2006 & $12: 285$ & 285 & 25.9 \\
\hline 2007 & $\begin{array}{l}27: 213 \\
\text { 29: } 210 \\
30: 210\end{array}$ & 211 & 21.1 \\
\hline 2008 & $8: 329$ & 329 & 36.5 \\
\hline 2011 & 9: 319 & 319 & 53.2 \\
\hline
\end{tabular}


In an effort to reflect on the past 47 years of publications on business-to-business marketing management in Industrial Marketing Management, this issue uses citation counts to select the articles with the greatest impact, focusing on and analyzing the 30 most cited articles from the journal, according to various factors.

\section{GENERAL OBSERVATIONS: CITATION CLASSICS IN INDUSTRIAL MARKETING}

\section{MANAGEMENT}

Sixty-five authors produced the 30 citation classics, for an average of 2.43 authors per article. In particular, for the top 10 cited classics, there were 20 authors, averaging 2.00 authors per article. For the next 10 classics, there were 29 authors, averaging 2.90 authors per article; and for the last 10 articles, there were 24 authors, averaging 2.40 authors per article. From these numbers, we find no apparent advantage in having more than 2 authors per article.

In terms of country origins, reflecting the country of the lead author, we find articles from 13 countries: 11 from the United States; 3 from Finland; and 2 articles each from Canada, Germany, Sweden, the Netherlands, and the United Kingdom. Finally, from Austria, Denmark, France, Hong Kong, India, and New Zealand, we identify 1 article each. Thus, of all citation classics, approximately $37 \%$ originated from the United States and $47 \%$ from Europe-figures that correspond well with the journal's international scope. For example, during Peter LaPlaca's editorship, $22 \%$ of authors claimed the United States as their home region, and $50 \%$ were from European countries.

Much of this spread of citation classics across the global stage can be attributed to the influence of the Industrial and Marketing Purchasing conferences. These important global business-to-business marketing and management academic events are well attended by current and future Industrial Marketing Management authors. In the 13 years between 2004 and 2016, 
12 annual IMP conferences were organized in 11 different European countries, which likely helps explain the high percentage of European citation classics.

Sixteen citation classics (53\%) involved empirical research, and a few articles simply drew on known case companies. It seems as if quantitative articles have a higher chance of being cited: $11(69 \%)$ of the empirical articles employed a quantitative methodology, and only $5(31 \%)$ employed a qualitative methodology. The remaining 14 citation classics were literature reviews, in some sense.

Of the 3,129 articles published in Industrial Marketing Management, 403 articles have prompted no citations since 1971. Starting in 2008 (the earliest date to obtain reliable citation data for the journal's current data set), 59 articles have been cited at least 59 times (i.e., the $\mathrm{h}$ index for articles in Industrial Marketing Management starting in 2008). The average number of citations for the 30 citation classics is about 348. With 1,126 citations, Lambert and Cooper's (2000) article is the most cited; Cretu and Brodie (2007) and Davies et al. (2007) are the least cited, each with 210 citations, but still well above the $\mathrm{h}$ index of 59. Since 2002, Industrial Marketing Management has evoked 21,292 citations; with their 5,388 citations, the citation classics (17 published in 2002 or later) account for a little over $25 \%$ of the total. Considering that it has published 1,346 articles since 2008, 1.26\% of the articles in Industrial Marketing Management (i.e., the 17 top citation classics) command more than $25 \%$ of the citations.

\section{TOPICS IN CITATION CLASSICS IN INDUSTRIAL MARKETING MANAGEMENT}

Sorting the 30 articles according to their topics, we identify eight major categories and two minor categories (the latter with one article each): supply chains (six articles), relationships and business networks (six articles), firm performance (four articles), value (six articles), goodsdominant and service-dominant logic (two articles), product innovation (two articles), Internet 
and high-technology markets (two articles), third-party logistics providers (one article), and system sellers and systems integrator (one article). However, several articles combine elements from two or more categories, such as Calantone et al. (2002), Davies et al. (1995), De Ruyter et al. (2001), Handfield and Bechtel (2002), Hult et al. (2004), Lancioni et al. (2000), Lindgreen and Wynstra (2005), Ulaga (2003), Walter et al. (2001), and Wu et al. (2006). In this section, we detail the thrust of each of these 30 reprinted articles.

\section{Supply Chains}

In the opening article to this special issue, "Issues in Supply Chain Management," Douglas M. Lambert and Martha C. Cooper (2000) discuss the critical role, and the ongoing challenge, of cross-functional integration and marketing for successful supply chain management. Their framework for supply chain management prompts key questions about how to implement this approach. In the same year, Martin Christopher (2000) published "The Agile Supply Chain: Competing in Volatile Markets," describing how turbulent markets have become normative. But with shorter life cycles and global uncertainty, slow-moving logistics pipelines also become unsustainably risky, such that he calls on organizations to reconsider the structure and management of their supply chains by adopting agility and increased responsiveness.

With their “A Portfolio Approach to Supplier Relationships," Rasmus Friis Olsen and Lisa M. Ellram (1997) worry about the lack of uses of portfolio models in marketing and purchasing, so they propose a three-step portfolio model to manage various kinds of supplier relationships and also offer a critique of portfolio models used in strategic planning. In another attempt at "Making the Most of Supplier Relationships," Lars-Erik Gadde and Ivan Snehota (2000) argue that resource-intensive partnerships with suppliers are justifiable only if the relationship benefits exceed the costs. Because of these costs, companies really can be closely involved with only a 
few suppliers, so they should pursue a variety of relationships, meaning that they also need the capacity to cope with those varied relationships in differentiated ways.

By studying "The Role of Trust and Relationship Structure in Improving Supply Chain Responsiveness,” Robert B. Handfield and Christian Bechtel (2002) instead suggest that to build trusting relationships, suppliers must invest in site-specific and human assets, and buyers must use contracts judiciously, reflecting the relative dependence in the relationship. Buyer dependence, supplier human asset investments, and trust appear positively related to supply chain responsiveness, and if buyers lack control over their suppliers, building trust can also improve supplier responsiveness. Finally, Ashish Agarwal, Ravi Shankar, and M. K. Tiwari (2007) describe the links among variables that influence supply chain agility in "Modeling Agility of Supply Chain." They categorize the variables according to their driving power and dependence, such that they clarify some of these complex variables and give supply chain managers new insights for their strategic planning to improve their supply chain agility.

\section{Relationships and Business Networks}

To identify the nature of the benefits that accrue from personal relationships (guanxi) and their relative importance, Howard Davies, Thomas K. P. Leung, Sherriff T. K. Luk, and Yiu-hing Wong (1995), rank “The Benefits of 'Guanxi': The Value of Relationships in Developing the Chinese Market." They propose an underlying, four-factor structure, comprising procurement, information, bureaucracy, and transaction smoothing. Achim Walter, Thilo Müller, Gabriele Helfert, and Thomas Ritter (2003) instead conceptualize the "Functions of Industrial Supplier Relationships and Their Impact on Relationship Quality." They propose that to the extent that a supplier fulfills direct and indirect relationship functions, the customer perceives more positive relationship quality, especially if that customer also can easily replace the supplier. Then with 
“An Evaluation of Divergent Perspectives on Customer Relationship Management: Towards a Common Understanding of an Emerging Phenomenon," Alex R. Zablah, Danny N. Bellenger, and Wesley J. Johnston (2004) analyze five relationship management perspectives: process, strategy, philosophy, capability, and technology-based. On the basis of this analysis, they argue that the ongoing process of customer relationship management requires developing and leveraging market intelligence to build and maintain a profit-maximizing portfolio of customer relationships.

This section's remaining three articles discuss relationships as business networks. For example, in "Managing in Complex Business Networks," Thomas Ritter, Ian F. Wilkinson, and Wesley J. Johnston (2004) consider the extent to which business networks are manageable and also how to measure a firm's ability to manage a network. They thus derive a set of propositions regarding which abilities firms need to manage complex business networks. Then Maria Bengtsson and Sören Kock (2000) address ““Coopetition’ in Business Networks- to Cooperate and Compete Simultaneously," with the notion that coopetition-such that two competitors compete and cooperate with each other—offers the most advantageous relationship. Yet it also is highly complex, depending on the degree of proximity to the customer, competitors' access to specific resources, and individual members' inability to demonstrate both logics at a time. Coopetition thus requires a division in the firm, either at the individual or division level. In this section's final article, "Business Relationships and Networks: Managerial Challenge of Network Era,” Kristian K. Möller and Aino Halinen (1999) propose a different network management framework, reflecting the managerial implications of industrial network theory, along with a synthesis of network management and its dualistic nature. 


\section{Firm Performance}

As we noted previously, in "Learning Orientation, Firm Innovation Capability, and Firm Performance," Roger J. Calantone, S. Tamer Cavusgil, and Yushan Zhao (2002) delineate four learning orientations: commitment to learning, shared vision, open mindedness, and intraorganizational knowledge sharing. They thus consider learning orientation as a second-order construct, with effects on firm innovativeness, which in turn influences firm performance. In a further consideration of why some industrial firms might be more innovative than others and what effects that innovativeness has, G. Thomas M. Hult, Robert F. Hurley, and Gary A. Knight (2004) investigate whether the link from innovativeness to firm performance depends on the environmental context in "Innovativeness: Its Antecedents and Impact on Business Performance." The model that they propose includes market orientation, entrepreneurial orientation, and learning orientation as antecedents of innovativeness, then a direct relationship from innovativeness to business performance, while also considering the influence of market turbulence.

In another article, "The Impact of Information Technology on Supply Chain Capabilities and Firm Performance: A Resource-based View," Fang Wu, Sengun Yeniyurt, Daekwan Kim, and S. Tamer Cavusgil (2006) provide a new perspective for evaluating information technology investments by proposing that information technology-enabled supply chain capabilities are both specific to the firm and hard-to-copy across organizations. Finally, Kurt Matzler, Franz Bailom, Hans H. Hinterhuber, Birgit Renzl, and Johann Pichler (1999) confirm asymmetric relationships between attribute-level performance and overall satisfaction in "The Asymmetric Relationship Between Attribute-level Performance and Overall Customer Satisfaction: A Reconsideration of 
the Importance-Performance Analysis." They also caution that conventional importanceperformance analyses offer misleading managerial insights and demand revision.

\section{Value}

In "Value Creation in Buyer-Seller Relationships: Theoretical Considerations and Empirical Results from a Supplier's Perspective," Achim Walter, Thomas Ritter, and Hans Georg Gemünden (2001) conceptualize value creation as direct and indirect functions of customer relationships that can be characterized according to performed activities and employed resources. These direct and indirect functions can enhance the value perceived by the supplier. In their review of literature pertaining to value in business markets, Adam Lindgreen and Finn Wynstra (2005) take business marketing, purchasing, and supply management perspectives in "Value in Business Markets: What Do We Know? Where Are We Going?" Their review highlights two levels of analysis: the value of goods and services versus the value of buyer-supplier relationships. Accordingly, they call for research that pursues insights into the value of products/relationships on the one hand and value analysis/creation/delivery on the other.

The third article, "Capturing Value Creation in Business Relationships: A Customer Perspective" by Wolfgang Ulaga (2003), suggests the growing importance of collaborative relationships in business markets; he also identifies eight drivers that create and deliver value in business relationships. Noting “Business Suppliers' Value Creation Potential: A Capabilitybased Analysis,” K. E. Kristian Möller and Pekka Törrönen (2003) seek to classify value creation according to efficiency, effectiveness, and network functions, such that the value creation process ranges from core to added to future value. Because it is easier to assess the potential of a supplier for core value than for added value or future value, customers might use suppliers' capability profiles to predict their suitability for particular value-creation projects. 
These authors accordingly provide a framework that links specific capabilities to different value production types.

Because delivering superior value to customers is an ongoing concern, Wolfgang Ulaga and Samir Chacour (2001) seek ways for "Measuring Customer-Perceived Value in Business Markets: A Prerequisite for Marketing Strategy Development and Implementation." With their multiple-item measure of customer-perceived value, they connect their proposed customer value audit to marketing strategy development techniques. In the section's final article, “The Influence of Brand Image and Company Reputation where Manufacturers Market to Small Firms: A Customer Value Perspective," Anca E. Cretu and Roderick J. Brodie (2007) consider how company's reputation might influence buying decisions, beyond the specific product-related influences of its brand's image, by exerting effects on perceptions of product and service quality, customer value, and customer loyalty.

\section{Goods-Dominant and Service-Dominant Logic}

The two articles in this section both were written by Stephen L. Vargo and Robert F. Lusch, the authors who largely introduced these two logics to the field. They define a goods-dominant (GD) logic as one that regards services as a type of (intangible) good, such that production and distribution practices for tangible goods simply can be modified to apply to services. But a service-dominant (S-D) logic instead identifies service-the process of using resources for the benefit of and in conjunction with another party—as the fundamental purpose of any economic exchange, such that it demands a revised, service-driven framework for all of marketing. Thus, in "From Goods to Service(s): Divergences and Convergences of Logics," Vargo and Lusch (2008) call the transition to a service-centered logic consistent with, and derived from, a similar transition in business marketing literature. The parallels have implications for marketing theory 
and for the transition to a SD logic. Then in "It's All B2B... and Beyond: Toward a Systems Perspective of the Market" (2011), they propose that all exchanges are business-to-business, so business-to-business marketing insights apply to mainstream marketing. A generic, actor-to-actor orientation implies dynamic, networked, systems orientations toward value creation, and Vargo and Lusch suggest ways to develop this notion into a general theory of the market.

\section{Product Innovation}

With their early publication, Robert G. Cooper and Elko J. Kleinschmidt (1987) argue in "Success Factors in Product Innovation" that managers must get better at selecting new products and managing the new product process if their companies are to survive. Robert G. Cooper (1988) also identifies gaps in industrial firms' predevelopment product innovation practices, suggesting that new product success (and failure) may be decided even before the new product project enters the development phase. Thus he again calls on managers to improve the effectiveness of their innovation processes.

\section{Internet and High-Technology Markets}

Richard A. Lancioni, Michael F. Smith, and Terence A. Oliva (2000), in "The Role of the Internet in Supply Chain Management," detail the specific uses of the Internet for various supply chain management operations (e.g., transportation, purchasing, inventory management, customer service, production scheduling, warehousing, vendor relations). Ko de Ruyter, Luci Moorman, and Jos Lemmink (2001) instead focus on high-tech markets in "Antecedents of Commitment and Trust in Customer-Supplier Relationships in High Technology Markets," noting their high levels of complexity and perceived risk, such that various factors lead to commitment and trust and thus to customers' intentions to stay in a relationship. With their model and results, these 
authors define the unique influences of different antecedents of trust, commitment, and intentions to stay in high-tech markets, emphasizing the critical role of affective commitment.

\section{Third-Party Logistics Providers}

Susanne Hertz and Monica Alfredsson (2003) are interested in the "Strategic Development of Third Party Logistics Providers" and how they balance general problem-solving capabilities against customer adaptation efforts. For example, new entrants appear strongly influenced by existing businesses and networks, but after gaining some experience, firms seek to offer more advanced, complex services. These authors also identify three particular issues for third-party logistics providers: the need for neutrality, the internationalization of their business, and the challenge of coping with strategic alliances, mergers, and acquisitions.

\section{System Sellers and Systems Integrator}

The only article in this final section, "Organizing for Solutions: Systems Sellers vs. Systems Integrator," examines how firms organize to provide integrated solutions; Andrew Davies, Tim Brady, and Michael Hobday (2007) propose a business model in which providing products and services represents an integrated solution to customers' needs. They identify two ideal types of organizations: vertically integrated systems sellers that produce all product and service components for a system and systems integrators that coordinates components obtained from external firms. Yet they also argue against the continued dominance of systems sellers and note that a simple transition to systems integration often is not possible, due to the more complex pattern of organizational forms that combines elements of both types.

\section{CONCLUDING REMARKS}

Industrial Marketing Management is accepted as the leading academic journal devoted to the study of business-to-business marketing management. Its high and increasing Impact Factor, and 
its appearance in most lists of top-rated marketing journals (regardless of ranking methodology used), attest to this fact. Since its inception in 1971, well over 3,000 articles have been published in the pages of this journal, covering a wide range of topics pertaining to business-to-business or industrial marketing management and strategy. The business-to-business marketing management literature stream has matured over this time, and Industrial Marketing Management articles are widely read and cited by marketing scholars, as well as academics in the areas of innovation, strategy, operations management, and supply chain management.

But such evidence portrays the evidence in relatively broad strokes. A finer-detailed view of the journal and its influence would consider that there are some specific articles that have been the most influential; the "best of the best" so to speak. These are the ones that have been cited the most times and have influenced and supported the research of the largest number of scholars. These articles are the most inspirational to young scholars, and have in many cases provided theoretical models that later academic researchers have been able to build upon to extend our theoretical understanding of the business-to-business marketing management process. This special issue is a tribute to the most influential articles that have appeared in the pages of Industrial Marketing Management, recognizing and honoring the specific impact each article has had on the field of business-to-business marketing.

As noted, the 30 citation classics can be classified into a relatively small number of topic areas: firm performance, goods-dominant/service-dominant logics, Internet/high-technology markets, product innovation, relationships and business networks, supply chains, and value (each with at least two articles among the 30), as well as systems sellers/integrators and third-party logistics providers (one article each among the 30). Considering these topic areas provides some clues as to the far-reaching impact of Industrial Marketing Management. Six of the classic 
articles study supply chain issues, while six investigate business relationships and networks, and two others are in the area of product innovation. These articles have influenced theory development in related academic disciplines such as supply chain management, strategic management, and innovation, as well as in mainstream marketing and business-to-business marketing. This is further evidence that the articles published in the pages of Industrial Marketing Management have far-reaching theoretical implications in fields outside mainstream marketing and are used extensively as theoretical support by colleagues in these fields. At the same time, classic articles studying isses such as firm performance (four articles), value (six articles), and goods-dominant/service dominant logic (two articles) are of interest to marketing academics in the broadest sense, as well as those in related areas such as strategic management. Though it is perhaps speculative to draw more conclusions from this in-depth study of only 30 articles (albeit the 30 most-cited articles), it is very reassuring to see the influence of Industrial Marketing Management and the authors published within its pages, in terms of contribution to the academic study of business markets.

Looking to the future, which research streams currently appearing in Industrial Marketing Management will be the most influential? Which articles appearing this year might be included in a list of classics twenty years from now? It is hard to predict, as the field of business-tobusiness marketing management research has become wider and more diverse in its research streams as it has matured. It is clear, however, that the rich literature found in Industrial Marketing Management will continue to influence business scholars in a wide range of academic disciplines, for years to come. 


\section{REFERENCES}

Agarwal, A., Shankar, R., \& Tiwari, M.K. (2007). Modeling agility of supply chain. Industrial Marketing Management, 36(4), pp. 443-457.

Bateman, A. (2012). Why I love the H-index. PLOS Biologue. Posted October 19, 2012.

Bengtsson, M. \& Kock, S. (2000). "Coopetition" in business networks: To cooperate and compete simultaneously. Industrial Marketing Management, 29(5), pp. 411-426.

Calantone, R.J., Cavusgil, S.T., \& Zhao, Y. (2002). Learning orientation, firm innovation capability, and firm performance. Industrial Marketing Management, 31(6), pp. 515-524.

Christopher, M. (2000). The agile supply chain: Competing in volatile markets. Industrial Marketing Management, 29(1), pp. 37-44.

Cooper, R.G. (1988). Predevelopment activities determine new product success. Industrial Marketing Management, 17(3), pp. 237-247.

Cooper, R.G. \& Kleinschmidt, E.J. (1987). Success factors in product innovation. Industrial Marketing Management, 16(3), pp. 215-223.

Cretu, A.E. \& Brodie, R.J. (2007). The influence of brand image and company reputation where manufacturers market to small firms: A customer value perspective. Industrial Marketing Management, 36(2), pp. 230-240.

Davies, A., Brady, T., \& Hobday, M. (2007). Organizing for solutions: Systems seller vs. systems integrator. Industrial Marketing Management, 36(2), pp. 183-193.

Davies, H., Leung, T.K.P., Luk, S.T.K., \& Wong, Y.-h. (1995). The benefits of "guanxi”: The value of relationships in developing the Chinese market. Industrial Marketing Management, 24(3), pp. 207-214. 
De Ruyter, K., Moorman, L., \& Lemmink, J. (2001). Antecedents of commitment and trust in customer-supplier relationships in high technology markets. Industrial Marketing Management, 30(3), pp. 271-286.

Franke, N. \& Schreier, M. (2008). A meta-ranking of technology and innovation managemententrepreneurship journals. Die Betriebswirtschaft, 68(2), 185-216.

Gadde, L.-E. \& Snehota, I. (2000). Making the most of supplier relationships. Industrial Marketing Management, 29(4), pp. 305-316.

Garfield, E. (1976). Is the ratio between number of citations and publications cited a true constant? Current Contents, 6 (February 9): pp. 419-421.

Handfield, R.B. \& Bechtel, C. (2002). The role of trust and relationship structure in improving supply chain responsiveness. Industrial Marketing Management, 31(4), pp. 367-382.

Hertz, S. \& Alfredsson, M. (2003). Strategic development of third party logistics providers. Industrial Marketing Management, 32(2), pp. 139-149.

Hirsch, J.E. (2005). An index to quantify an individual's scientific research output. Proceedings of the National Academy of Sciences, Vol. 102, 16569-16572.

Hult, G.T.M., Hurley, R.F., \& Knight, G.A. (2004). Innovativeness: Its antecedents and impact on business performance. Industrial Marketing Management, 33(5), pp. 429-438.

Lambert, D.M. \& Cooper, M.C. (2000). Issues in supply chain management. Industrial Marketing Management, 29(1), pp. 1-16.

Lancioni, R.A., Smith, M.F., \& Oliva, T.A. (2000). The role of the internet in supply chain management. Industrial Marketing Management, 29(1), pp. 45-56.

Lindgreen, A. \& Wynstra, F. (2005). Value in business markets: What do we know? Where are we going? Industrial Marketing Management, 34(7), pp. 732-748. 
Matzler, K., Bailom, F., Hinterhuber, H.D., Renzl, B., \& Pichler, J. (1999). The asymmetric relationship between attribute-level performance and overall customer satisfaction: A reconsideration of the importance-performance analysis. Industrial Marketing Management, 33(4), pp. 271-277.

Michalos, A.C. (2005). Citation Classics from Social Indicators Research. Dordrech: Springer.

Michalos, A.C. and Poff, D.C. (2013). Citation Classics from the Journal of Business Ethics: Celebrating the First Thirty Years of Publication. Dordrecht: Springer.

Möller, K.E.K. \& Törronen, P. (2003). Business suppliers’ value creation potential a capabilitybased analysis. Industrial Marketing Management, 32(2), pp. 109-118.

Möller, K.K. \& Halinen, A. (1999). Business relationships and networks: Managerial challenge of network era. Industrial Marketing Management, 28(5), pp. 413-427.

Olsen, R.F. \& Ellram, L.M. (1997). A portfolio approach to supplier relationships. Industrial Marketing Management, 26(2), pp. 101-113.

Pendlebury, D.A. (1991). Science, citation and funding (Letter to the Editor). Science, 251: pp. 1410-1411.

Ritter, T., Wilkinson, I.F., \& Johnston, W.J. (2004). Managing in complex business networks. Industrial Marketing Management, 33(3), pp. 175-183.

Times Higher Education (2011). Citation averages, 2000-2010, by fields and years. https://www.timeshighereducation.com/news/citation-averages-2000-2010-by-fields-andyears/415643.article. Accessed September 12, 2017.

Touzani, M. \& Moussa, S. (2010). Ranking marketing journals using the search engine Google Scholar. Marketing Education Review, 20(3), 229-247. 
Ulaga, W. (2003). Capturing value creation in business relationships: A customer perspective. Industrial Marketing Management, 32(8), pp. 677-693.

Ulaga, W. \& Chacour, S. (2001). Measuring customer-perceived value in business markets: A prerequisite for marketing strategy development and implementation. Industrial Marketing Management, 30(6), pp. 525-540.

Vargo, S.L. \& Lusch, R.F. (2008). From goods to service(s): Divergences and convergences of logics. Industrial Marketing Management, 37(3), pp. 254-259.

Vargo, S.L. \& Lusch, R.F. (2011). It's all B2B... and beyond: Toward a systems perspective of the market. Industrial Marketing Management, 40(2), pp. 181-187.

Walter, A., Müller, T.A., Helfert, G., \& Ritter, T. (2003). Functions of industrial supplier relationships and their impact on relationship quality. Industrial Marketing Management, 32(2), pp. 159-169.

Walter, A., Ritter, T., \& Gemünden, H.G. (2001). Value creation in buyer-seller relationships: Theoretical considerations and empirical results from a supplier's perspective. Industrial Marketing Management, 30(4), pp. 365-377.

Wu, F., Yeniyurt, S., Kim, D., \& Cavusgil, S.T. (2006). The impact of information technology on supply chain capabilities and firm performance: A resource-based view. Industrial Marketing Management, 35(4), pp. 493-504.

Zablah, A.R., Bellenger, D.N., \& Johnston, W.J. (2004). An evaluation of divergent perspectives on customer relationship management: Towards a common understanding of an emerging phenomenon. Industrial Marketing Management, 33(6), pp. 475-489. 